\title{
„Męska przyjaźń". Kilka uwag o kondycji męsko-męskich relacji we współczesnej kulturze Zachodu
}

Bartek Lis

Muzeum Współczesne, Wrocław

\begin{abstract}
W eseju autor przedstawia społeczne ramy współczesnego dyskursu o męsko-męskich relacjach/stycznościach w przestrzeni (o różnym charakterze: od incydentalnych, koleżeńskich po przyjacielskie) szczególną uwage zwracając na te, w których jeden z podmiotów jest mężczyzną w dominującym stopniu homoseksualnym. Autor ilustruje swoje wnioski i komentarze fragmentami wywiadów z gejami, które przeprowadził podczas pracy nad swoim doktoratem.
\end{abstract}

Bardzo wiele zostało już napisane na temat społecznej/kulturowej produkcji „nowych gatunków” ludzi. Potrzeba porządkowania i organizowania przestrzeni wymagała systematyzacji istniejącej wiedzy, uzupełniania jej lub (nie bójmy się tego słowa) wymyślania. Michel Foucault (2000) jest oczywiście tylko jednym z wielu autorów i autorek, którzy na polu współczesnej humanistyki starali się odtworzyć ten proces - różnie w czasie lokując jego początki, jednak dość zgodnie charakteryzując skutki. Jego opowieść o ludzkiej seksualności, jej dyskursywizowaniu i sfunkcjonalizowaniu, bierze za jeden z przykładów zagadnienie homoseksualności w kontekście europejskim/zachodnim.

Produkcję nowej, odmieńczej tożsamości oparto wyłącznie na istnieniu uzyskiwanej przez część osób innej satysfakcji seksualnej niż ta najczęściej rozpowszechniona. Dwóch mężczyzn lub dwie kobiety incydentalnie wyróżniających swoje ciała - albo też (co wcale tak rzadkie nie było) budujących swoje pragnienia, fantazje i codzienne praxis w oparciu o drugą osobę tej samej płci zostało "wyróżnionych" jako odszczepieńczy gatunek (Foucault 2000: 45). Nie sam fakt wyabstrahowania homoseksualności z morza innych, w tym dominujących, praktyk seksualnych jest tutaj szczególnie znaczący, lecz właśnie posłużenie się tą kategorią przez reżimy do porządkowania - nie tylko symbolicznej - przestrzeni zachodniego świata. Negatywne nacechowanie figury homoseksualisty - przedstawienie go jako dewianta i "aberrata” - pozwoliło ustawić 
heteroseksualność na pozycji jedynej wytłumaczalnej i zdrowej normy (która notabene została w ten sposób wtórnie wynaleziona). Homoseksualność w zachodniej kulturze stała się cechą o nędznej proweniencji, świadczącą o z góry zakładanych kiepskich walorach moralnych osoby, którą miałaby ona opisywać; cechą - co równie istotne w kontekście androcentrycznej kultury Zachodu dowodzącą niemęskości męskiego podmiotu. Dyskryminacja tych, których homoseksualności jesteśmy pewni, albo której się domyślamy (operując dostępnym i rozpowszechnionym stereotypem o zniewieścieniu sodomitów), służy nie tylko napiętnowaniu i karaniu seksualnych dysydentów, lecz ma także spełniać funkcję oddalenia podejrzeń o własną homoseksualność. Zważywszy na niski status tejże w naszej kulturze, wskazane jest budowanie fizycznego oraz symbolicznego dystansu pomiędzy mężczyznami, jak również takiego zarządzania „bliskością", by wnioski dla obserwatora były jednoznacznie świadczące o heteroseksualności rzeczonych. Ciągnie to za sobą bardzo konkretne konsekwencje dla konstrukcji i jakości nie-erotycznych, nieseksualnych relacji męsko-męskich.

Homofobia stanowi przeszkodę w nawiązaniu bliskich, intymnych przyjaźni między mężczyznami (Connell 2005: 133). Mityczna opowieść o męsko-męskim braterstwie może tak naprawdę zaistnieć jedynie na polu bitewnym albo w innych ekstremalnych warunkach, a i wtedy wymuszona cielesna bliskość nie jest wolna od komentarzy suponujących homoseksualność (Spartiaci - kochankowie walczący pod Termopilami - są tego najlepszym przykładem). Kres męskiej, romantycznej przyjaźni jest jednak silnie powiązany z historią najnowszą. Michel Foucault koniec bliskich relacji pomiędzy mężczyznami łączy z zagęszczeniem dyskursu na temat seksualności, jako że współcześnie homoseksualność zyskała status oddzielnej kategorii tożsamościowej, zamiast stanowić jeden z wielu sposobów realizacji erotycznych pragnień (Davis 2004; Garlick 2002: 261). Francuski filozof w jednym z wywiadów miał powiedzieć: „Zniknięcie przyjaźni jako społecznej instytucji oraz ustanowienie homoseksualności jako społecznego/politycznego/medycznego problemu, są ze sobą powiązane" (Nardi 1992b: 184).

Jak twierdzi John Boswell (2006), stosunek do męskiej homoseksualności różnił się zależnie od miejsca i czasu (seksualne relacje kobiet nie były aż tak "widoczne”, dzięki istnieniu zasady każącej skupiać największą uwagę na mężczyznach i „ich sprawach”). Przez bardzo długi okres, seksualnych „występków” mężczyzn nie łączono z całościową wizją homoseksualisty/odmieńca, którego opis byłby jednoznacznie negatywny - a co najważniejsze - wykluczający "męskość" jako cechę mu 
dostępną. Socjolog Peter Nardi zauważa, że w momencie, gdy seksualne kontakty przedstawicieli tej samej płci zaczęły być medykalizowane (XIX wiek) i stygmatyzowane, przekonanie o perwersyjności tych stosunków zostało przeniesione na całość bliskich relacji męsko-męskich (dotyczyło to także kobiet, choć w mniejszej skali). Oznaczało to początek końca męskości, rozumianej jako "romantyczna wspólnota” (1992a: 1). Pojawienie się nowych definicji i koncepcji ludzkiej seksualności skutkowało stopniowym rekonfigurowaniem kategorii "męskiej romantycznej przyjaźni". Zakładało to nie tylko fizyczne oddalenie korpusów w przestrzeni (wcześniej pocałunek dwóch mężczyzn wcale nie musiał być interpretowany jako przejaw seksualnego zainteresowania), ale również wymagało przeformułowania podstaw i warunków "męskiej przyjaźni” w taki sposób, by jakiekolwiek suponowanie homoseksualnych pragnień było niemożliwe. Obowiązującą zasadą stało się postrzeganie emocjonalnego dystansu oraz agresji/rywalizacji jako jedynych akceptowalnych zachowań (Jeleniewski-Seidler 2007).

Matthew Oransky i Jeanne Marecek (2009) są autorami badania, które wzięło pod lupę relacje między uczniami szkoły średniej pod kątem budowania tożsamości płciowej. Badacze przeprowadzili częściowo ustrukturyzowane, pogłębione wywiady z chłopcami wywodzącymi się z klasy średniej. Na podstawie badania wysnuto wnioski na temat życia emocjonalnego i tożsamościowych praktyk młodych, dorastających mężczyzn w Stanach Zjednoczonych. Badani zwracali uwagę, że jeśli miejsce miała sytuacja, w której doświadczali przemocy, to starali się nie okazywać emocjonalnego i/lub fizycznego bólu, zaś odnosili się z pogardą do tych chłopców, którzy na okazywanie bólu sobie pozwalali. W rozumieniu badanych, męskość oznaczała „bycie wytrzymałym" oraz konieczność nieokazywania uczuć. Sygnalizowali dodatkowo, że ich rówieśnicy określali zachowania, będące oznaką odczuwanego bólu, niepokoju lub troski, mianem "gejowskich" lub "dziewczęcych". Chłopcy opisywali interakcje z rówieśnikami tej samej płci jako zasadnicze i centralne dla rozumienia własnej męskości. Nawzajem stosowali praktyki drwienia, zaczepiania i fizycznego sprawiania sobie bólum a choć takie działania przynosiły im cielesny i psychiczny dyskomfort, to jednak uznawali je za celowe i wartościowe z punktu widzenia "doskonalenia" męskości - swojej oraz innych chłopców. Jak uważa Brett Stoudt, dla niektórych takie "rytuały" mogą być również oznaką zacieśniania specyficznie rozumianej męskiej przyjaźni, która nie potrafi przyjmować bardziej tradycyjnych form (2006: 281). Bliskość jest możliwa tylko wtedy, gdy osadzona jest w szerszym, „agresywnym kontekście”. 
Dodatkowo, Eric Anderson uważa, że sport współcześnie jest jedną z wiodących aktywności, które definiują męskość w kulturze masowej (2006: 202). Sportowa rywalizacja zastępuje niegdysiejsze rytuały przejścia, stanowiąc jedyną "naturalną" i akceptowalną (społecznie bezpieczną) formę współwystępowania mężczyzn w przestrzeni publicznej. Sport pozostaje testem, do którego mężczyźni w zachodnich społeczeństwach podchodzą, chcąc udowodnić swe męstwo. Pozostaje on bastionem hegemonicznej męskości, a tym samym wpisanego w nią heteroseksizmu oraz homofobii.

Sport odgrywa istotną rolę w procesie socjalizacji płciowej i decyduje nie tylko o wyćwiczeniu cielesnych umiejętności. Osiągnięcie określonych fizycznych kompetencji ma również swój wymiar społeczny/genderowy (Connell 2005: 35). Chłopcy zachęcani do gry w piłkę nożną (w tę sportową aktywność najczęściej bowiem angażują się na zajęciach wychowania fizycznego) uczą się „zdobywać" przestrzeń przeciwnika - drugą połowę boiska - oraz bronić swojej części pola. Brian Pronger zauważa, że gry zespołowe są jednymi z najbardziej męskich sportów, gdyż są zorganizowane wokół idei przestrzennej dominacji, która to może metaforycznie ilustrować większość relacji męsko-męskich we współczesnych, zachodnich społeczeństwach (1999: 382). Inne dyscyplin - jak na przykład tenis czy pływanie - mimo że również operują w przestrzeni, opierając się na rywalizacji i współzawodnictwie, to jednak są zwykle postrzegane jako mniej kontaktowe i nie zakładające przekraczania "linii" przeciwnika. Jako aktywności mniej brutalne i mniej ekspansyjne, nie są one uznawane za najbardziej „szlachetne” (tutaj: męskie) ze sportów.

Praktycznie wszystkie sporty są podzielone zależnie od płci zawodnika/zawodniczki. Skutkuje to tym - jak dowodzi Pronger - że mogą być interpretowane homoerotycznie (1999: 374). W przypadku mężczyzn homoerotyka sportu zasadza się na to cielesnej bliskości (czasami zakładającej bezpośredni dotyk - także w miejscach intymnych - np. w przypadku zapasów) i nagości (pod prysznicem, w szatni), czyli na wystarczająco wielu przesłankach, by tak zdefiniowaną sytuację uznać za seksualnie wieloznaczną (Plummer 2006: 129-130). Dla dbających o status „prawdziwego (czyli heteroseksualnego) mężczyzny", niezbędnym staje się uruchomienie zachowań, które będą odsuwały jakiekolwiek podejrzenie o homoseksualizm. Stąd wynika fakt, że w sporcie - a szczególnie w przypadku kontaktowych gier zespołowych (piłka nożna, football amerykański, rugby, koszykówka, hokej) - mamy do czynienia z najmniej dyskretnymi przykładami homofobii (Plummer 2006: 128). Dbałość o "seksualną czystość", manifestująca się kompulsywnym odcinaniem 
się od jakichkolwiek skojarzeń z homoseksualnością, ma być metodą demontującą tę wieloznaczność (Whitson 1990: 27). Homofobia w sporcie pełni zatem ważne strukturalne, społeczno-kulturowe funkcje, zapobiegając rozwinięciu skojarzeń usprawiedliwionych ikonograficznym kontekstem. Pozwala, by mężczyźni nadal mogli przebywać w swoim ekskluzywnym towarzystwie, bez ryzyka nadszarpnięcia "męskiej reputacji”.

Raewyn Connell zwraca uwagę, że relacje pomiędzy gejem a heteroseksualistą należą do szczególnie nadzorowanych i kontrolowanych we współczesnym zachodnim świecie (2005: 143). Większości gejów doskonale znany jest symboliczny lęk, jaki towarzyszy męskiej heteroseksualnej większości w kontaktach z homoseksualistami. Mężczyzna, którego homoseksualność jest już ujawniona, wchodzi w relacje z innymi mężczyznami, starając się tak zarządzać swą seksualną odmiennością, by nie przeszkadzała ona innym. Wycofanie się z uczestniczenia w sytuacjach wymagających cielesnej bliskości i nagości jest uznawaniem psychicznego oraz społecznego komfortu heteroseksualnych mężczyzn za priorytetowy. Rozpoznawszy dwuznaczność i kłopotliwość zbyt intymnych kontaktów gejów z heteroseksualistami, niektórzy mężczyźni zwiększają fizyczny dystans lub dokonują antycypującego „wypisania się" z tego typu sytuacji (Connell 2005: 156). W taki sposób, między innymi, starał się postępować Jason - jeden z rozmówców w badaniu Andersona dotyczącym homoseksualnych sportowców (2006: 209). Mężczyzna przyznał, że jeden z powodów, który powstrzymywał go przed ujawnieniem swojej orientacji, związany był z niepokojem o to, jak ujawnienie się wpłynie na stosunki z kolegami z drużyny - a zwłaszcza na krępujące sytuacje z przebieralni. „Nie chciałem, by inni czuli się niekomfortowo w moim towarzystwie, zwłaszcza w sportowej szatni" - wyznał respondent. Jawny gej będzie zatem unikał, na przykład, wspólnego przebierania w szatni z poinformowanymi o jego homoseksualności mężczyznami, gdyż nauczył się odczytywać taką sytuację jako niewygodną dla heteroseksualnych mężczyzn. Jest to niejako przyjęcie i akceptacja absurdalnej narracji o tym, że geje próbują uwieść każdego mężczyznę, który jest w ich polu widzenia - nieważne, jak atrakcyjny ów mężczyzna by nie był. Również we własnych badaniach, realizowanych przy okazji pracy nad doktoratem poświęconym problematyce gejowskich (nie)męskości ${ }^{1}$, odnalazłem przykłady

${ }^{1}$ W okresie od kwietnia do grudnia 2008 roku przeprowadziłem 40 pogłębionych wywiadów, które trwały średnio dwie, dwie i pół godziny. Poprzedzało je badanie pilotażowe, które umożliwiło przetestowanie oraz uzupełnienie pytań badawczych. Wszystkie rozmowy były rejestrowane, o czym badani byli poinformowani, a następnie transkrybowane i kodowane. Imiona, pod którymi występują respondenci, nie są prawdziwe. Respondentów do rozmów rekrutowałem za pomocą ogłoszeń na internetowych forach (gejowo.pl, innastrona.pl, hape.pl), poprzez lokalną organizację LGBTQ (Kampania Przeciw Homofobii Wrocław) oraz metodą „śnieżnej kuli” (zaczynając od znajomych homoseksualnych mężczyzn, następnie prosząc o skontaktowanie z kolejnymi osobami). Wszystkie wywiady były przeprowadzone w dużych i wielkich miastach (aby uniknąć ryzyka, że w próbie będą osoby 
ilustrujące skutki działania przemocy symbolicznej w tym obszarze. Dziewiętnastoletni Adam wykluczył się z uczestnictwa w treningach w momencie, gdy dokonał klasowego coming-outu. Uznał, że jego koledzy mogą nie czuć się dobrze we wspólnej przebieralni. Pytanie tylko, czy bardziej niepokojące miałoby być dla nich odsłanianie własnej nagości, czy też raczej oglądanie obnażonego gejowskiego ciała?

Później przyszło liceum i... to był szok, na przykład dla mojej mamy, że ja przestałem ćwiczyć, prawda. Po prostu załatwiłem sobie zwolnienie lekarskie i przez całe liceum nie ćwiczyłem. To był taki szok dla otoczenia. Przychodzi sobota, biegam $10 \mathrm{~km}$, a nie ćwiczę na wuefie. Ja uważałem, po prostu wychodziłem z założenia, że... bo ja się wyatutowałem od razu, [...] że będę w ten sposób fair wobec właśnie, wobec moich kumpli, z którymi po szkole chodzę, nie wiem, na picie itd. Więc ja uważałem po prostu, że to będzie fair jak ja nie będę ćwiczył na wuefie, jakoś nie będę wchodził w ich sferę intymności, a ja za to na przykład będę miał jakieś większe poczucie komfortu. (Adam: 19)

Inny mój rozmówca, Kamil, opowiadał o heteroseksualnym współpracowniku, z którym ściśle i intensywnie współpracował nad projektem wystawy (w czasie, gdy ja prowadziłem ów wywiad). Kamil zwierzył mi się z części obaw, jakie nowa znajomość w nim wywołuje, a zwłaszcza z tych związanych ze skracaniem dystansu oraz z potencjalnym niebezpieczeństwem wystąpienia niekompatybilności doświadczeń/wyobraźni.

Wydawało mi się, że byłoby bardzo źle, gdybym ja zakumplował się z nim do takiego stopnia, że zaczęlibyśmy się sobie zwierzać z naszych pierwszych miłości. Później się bałem tych jego reakcji, co będzie, jak ja mu powiem, że np. z pierwszym facetem bzykałem się, jak miałem 14 lat. Jak on na to zareaguje, co on

\footnotetext{
tylko z jednego kręgu towarzyskiego, wywiady realizowałem na terenie kilku miast: Wrocławia, Gdańska, Warszawy i Bielska Białej), jednak również perspektywa małych miast i wsi jest reprezentowana w badaniu - wielu respondentów pochodziło z takich miejscowości, a dopiero przyjazd na studia zmienił (możliwe, że tymczasowo) ich miejsce pobytu. Najmłodszy z respondentów w momencie przeprowadzania wywiadu miał 17 lat, najstarszy zaś 69 lat. Średnia arytmetyczna wynosi 27 lat. Dominującą grupę rozmówców stanowili ludzie młodzi (do 35 roku życia) - podyktowane jest to większą dostępnością dla badacza osób właśnie z tej kategorii wiekowej. Proces badawczy był możliwie obiektywizowany (metody i techniki zbierania danych) również poprzez triangulowanie zastosowanych metod. Podstawowe narzędzie, czyli bezpośrednie wywiady z homoseksualnymi mężczyznami, były uzupełniane obserwacją uczestniczącą (w okresie od 2006 roku wizyty w dyskotekach adresujących swoją ofertę do osób LGBTQ), co pozwalało również sformułować pewne uwagi na temat cielesnych/tekstylnych zachowań konkretnej podkategorii osób homoseksualnych, to jest bywalców klubów. Dodatkowo zdecydowałem się na analizę treści listów i ogłoszeń publikowanych przez gejów na łamach czasopisma "Inaczej” oraz portalu gejowo.pl.
} 
sobie o mnie pomyśli. To były tego typu obawy bardziej, a nie o to, że on jest biały, heteroseksualnym mężczyzną. Bałem się bardziej tego przejścia do relacji bardziej intymnych. (Kamil: 28)

O potrzebie terytorialnego, przestrzennego oddalania się anatomicznych mężczyzn - a zwłaszcza oddalania się od tych, co do których może istnieć podejrzenie, że są homoseksualni - dowodzi moja rozmowa z Miłoszem, której fragment znajduje się poniżej:

M: Gdy wchodziłem do ubikacji męskiej i też się specjalnie nie starałem, żeby się przerobić [...] ludzie potrafili wyprosić mnie z tej męskiej ubikacji, że "chyba mi się coś pomyliło", i tak dalej.

BL: Potrafili tak zrobić?

M: No. Były takie sytuacje. To było takie czasami no frustrujące może z lekka, że jednak kurcze, ten bat społeczny ciągle gdzieś tam jest. W takich niespodziewanych sytuacjach nawet [...].

BL: Ale oni cię próbowali wyprosić, ponieważ wiedzieli, że jesteś gejem? Czy z jakiegoś innego powodu?

M: Oni nie wiedzieli czym jestem. Generalnie zareagowali tak.

BL: Ale na pewno wiedzieli, że nie przystajesz do ich wyobrażenia o tym kim mężczyzna jest. I to ich tak niepokoiło.

M: No. (Miłosz: 25)

Tożsamość chłopców/mężczyzn, którzy myślą o sobie jak o heteroseksualistach w chwili uruchamiania określonych zachowań, które my nazwalibyśmy homofobicznymi, jest z pewnością bardzo krucha i nieposiadająca mocnych, pozytywnych fundamentów. Jakiekolwiek podejrzenie o niemęskość (homoseksualność) potrafi wybić ich z pewności. Uniemożliwia to tym samym nawiązanie z drugim mężczyzną „romantycznej przyjaźni”, która nie jest wariacją na temat rywalizacji i agresji.

A: Były takie dwie sytuacje. Między innymi mieliśmy spać na jednym łóżku [z heteroseksualnym kolegą - BL], to rozkładane, on spał na skraju łóżka, jak 
najdalej ode mnie, bo nie wiem, jakikolwiek kontakt odpada. Była też taka druga sytuacja, siedział sobie na kanapie w ten sposób.

$\mathrm{BL}$ : W sensie rozłożone ręce.

A: Tak. Ja skończyłem malować, podszedłem. Siadałem tak ciężko, uderzyłem plecami o oparcie i jego ręka osunęła się mi na ramię. Oczywiście ja uśmiech i drę sobie z niego łacha, a on się obraził, od razu zabrał rękę, zaczął mnie przepraszać. (Arek: 24)

Co ciekawe, drażliwość takiego przestrzennego zbliżenia dwojga mężczyzn o różnej orientacji seksualnej - zwłaszcza gdy odbywa się ono w intymnym kontekście - może zmienić się w sytuację, która, przy bliższym poznaniu, ma szanse rozwinąć się w stronę tradycyjnej (romantycznej) przyjaźni. Heteroseksualny mężczyzna wchodzący w bliskie, koleżeńskie kontakty z gejem może czuć się mniej obserwowany oraz kontrolowany pod kątem spełniania wymogów męskości (Fee 2000).

Wśród bliskich znajomych mam też mężczyzn heteroseksualnych. Oni wiedzą. To są bardzo bliskie znajomości, jestem często jedyną osobą dla takiego faceta, której on potrafi się zwierzyć, że np. ryczy po nocach, bo go dziewczyna zostawiła. Czyli wniosek byłby taki, po części, jestem osobą, przed którą nie muszą udawać, że męskość to jest niepłakanie. Przy czym ja nie robiłem żadnego ruchu w tą stronę - nie pisałem komuś mejla, "słuchaj płaczę i jestem gejem, w związku z powyższym możesz się wypłakać na moim ramieniu". (Paweł: 27)

Mężczyzna heteroseksualny może w takich sytuacjach pozwolić sobie na większą otwartość, emocjonalność, narracyjność - inaczej niż wtedy, gdy przebywa w towarzystwie mężczyzn, o których wiadomo, że są wyłącznie heteroseksualni (a jest tak zawsze, gdy podmiot wprost nie oznajmi swej seksualnej nienormatywności). Dzieje się tak z jednej strony w związku ze zinternalizowaniem norm roli męskiej, z drugiej zaś strony jest to efekt przyjęcia stereotypu geja jako kogoś niemęskiego, uczuciowego, "kobiecego". Nie ma zatem zagrożenia, że będzie on oceniany pod względem spełniania "przykazań męskości”, więc może się poczuć bardziej swobodnie. Taki mężczyzna otrzymuje chwilową przepustkę z Benthamowskiego panoptikonu (Foucault 1993), choć nigdy nie jest to działanie w pełni uniezależnione od społecznego kontekstu. 
Trudno, ot tak po prostu, wyłączyć płciową kontrolę i odłożyć na bok zasady, którym ktoś stara się sprostać od chłopięcości. Pozostaje świadomość, że niewinna, czysta relacja z „przyjacielem gejem” narażona jest na interpretację otoczenia zagrażającą społecznemu wizerunkowi. Ostatnia rzecz, którą trzeba brać pod uwagę, to fakt, że ów "lekceważony" ze względu na swoją męskość gej może sam strzec płciowej normatywności, skoro przechodził podobną genderową socjalizację.

Niektórzy z moich rozmówców, opowiadając o okresie dzieciństwa bądź dojrzewania, wspominali, że łatwiej nawiązywali kontakty z dziewczynkami niż z innymi chłopcami ${ }^{2}$. Zwracali uwagę, że kontakty te charakteryzował mniejszy poziom rywalizacji, swoboda, czy też brak konieczności udowodnienia czegokolwiek. Owym respondentom towarzyszyła często również niechęć do jednego z opisanych przez Debbie Epstein (2006) elementów konstytuujących "chłopięcą męskość" - bójek wewnątrz własnej grupy płciowej oraz zaczepiania dziewcząt.

Jeśli chodzi o kolegów to w większości to były koleżanki (śmiech), nie miałem zbyt wielu kolegów. Nie preferowałem takich męskich zabaw. Jak mówi moja mama: „zawsze wolałeś zbierać kwiatki, bawić się z babcią, zamiast się bawić w wojnę z kolegami". Także bardziej na takich dziewczyńskich zabawach mi to dzieciństwo upłynęło, bardziej to mi się podobało, może też dlatego że wychowałem się wśród dominujących kobiet bo wokół mnie było wiele kobiet, z mężczyzn to był tylko tata, jakiś tam wujek i dziadkowie, a tak same kuzynki, siostra, mama, babcie. [...] Bardzo lubiłem się bawić w sklep, w dom, z kolegami w sumie, nigdy jakiegoś kontaktu nie miałem. Chłopcy byli gdzieś tam, ale ja z koleżankami mieliśmy swój świat. Nigdy nie angażowałem się w jakieś typowe męskie zabawy, jak np. piłka nożna, której nie znoszę, nienawidzę jej. Chłopacy w przedszkolu byli zawsze przyzwyczajeni, że ja trzymam z dziewczynami i robimy swoje rzeczy, a oni swoje, po prostu nie wchodziliśmy sobie w drogę. To było z góry ustalone, to był podział ról: ja robię swoje, oni robią swoje, oni biegają po boisku, my tam sobie byliśmy na jakiejś łączce, nie było z tym żadnego problemu. To się zmieniło dopiero w gimnazjum. (Przemek: 20)

\footnotetext{
${ }^{2}$ Peter Nardi (1992b: 181) podaje wyniki niereprezentatywnych badań z 1988 roku, zgodnie z którymi aż 82\% respondentów (gejów) wskazało, że ich najlepszym przyjacielem był inny gej lub biseksualny mężczyzna. Tylko dla mniej niż 10\% odpowiadających najbliższym przyjacielem - inaczej niż podaje stereotyp - była heteroseksualna kobieta.
} 
Ja pamiętam, że ... Właśnie odkąd pamiętam to lubiłem się bawić z dziewczynami. Miałem całą masę przyjaciółek, znajomych, koleżanek. Z chłopcami to tak nie bardzo, wkurzali mnie strasznie, oni gdzieś latali, mieli jakieś durne zabawy, typu strzelanie. Mnie to zupełnie nie interesowało, ale to jakoś całkiem naturalnie wychodziło - wspólny język, i jak się jakieś przyjaźnie zawiązywały to to zawsze były dziewczyny, nawet nie wiem jak to się działo. Mam jeszcze starszą o rok siostrę, to jest bardzo podobny wiek, ona też miała wokół siebie same koleżanki, więc wokół było więcej dziewczynek niż chłopców. One często jakiś kocyk przynosiły, wykładały na trawniku, wyciągały lalki - ja zawsze w tym uczestniczyłem. W gumę się grało, w klasy, coś w tym stylu. Oczywiście chłopcy bardzo szybko zaczęli rzucać takimi wyzwiskami w stylu "babiarz", no i takie historie. (Kuba: 27)

Odpowiadając na pytanie o dziecięce znajomości i zabawy, Kuba oraz Przemek potwierdzają stereotyp geja znajdującego swoje miejsce w centrum „babińca”. Oczywiście, opowieść ta nie jest reprezentatywna dla wszystkich homoseksualnych mężczyzn (o czym za chwilę). W tym miejscu chciałbym jedynie zwrócić uwagę, że rozmówcy mówili o tym zjawisku z uśmiechem - wyczuwalny był dyskretny wstyd. Zażenowanie sytuacją, że nigdy nie mieli „męskich" (czytaj: heteroseksualnych) przyjaciół, a tym samym, że ich przyjaźnie nie są tymi prawdziwymi, odnosi się do archetypu męskiej przyjaźni, chłopięcych zabaw i baśniowej „Nibylandii” z prozy Jamesa Matthew Barrie'go. Socjolog Dwight Fee (2000: 57-58) na podstawie swoich badań doszedł do wniosku, że dla wielu homoseksualnych mężczyzn przyjaźń z innymi mężczyznami (zwłaszcza jeśli są oni heteroseksualni) jest czymś pożądanym i możliwe, że - przez fakt jej rzadszego doświadczania - bardziej wartościowym. Nie można również wykluczyć, że przyjaźnienie się chłopca z dziewczynką wyciąga go symbolicznie z męskiego porządku i lokuje po tej "gorszej”, dziewczęcej stronie. Z pewnością, przyjaźń dwóch chłopców jest bezpieczniejsza, jeśli chodzi o ocenę rówieśników. Potwierdza to Patryk:

Zawsze gdzieś mnie bolało, że w liceum... bo w podstawówce to jeszcze z dziewczynami i chłopakami, a w liceum to już tylko ciągle trzymałem się z dziewczynami i to mnie właśnie bolało, bo wtedy jeszcze się bardzo liczyłem z opinią co ludzie powiedzą. Bolało mnie, że ja nie mam kontaktu z tymi chłopakami, że oni trzymają się razem, a ja nie jestem z nimi i jak 
ja jestem odbierany? Że ja jestem inny, i wiadomo od razu wszyscy coś sobie pewnie myślą - "co jest z nim nie tak?" I to było dla mnie jakąś traumą. (Patryk: 24)

Otaczanie się samymi dziewczynkami w okresie przedszkolnym i wczesnoszkolnym może być podstawą do zakwestionowania "chłopięcości” chłopca - tak samo jak niewykluczone, że brak żeńskiego towarzystwa w okresie dojrzałym może skutkować suponowaniem homoseksualności mężczyzny. Patryk wyczuwał tę presję i uznawał wagę posiadania "męskich" przyjaciół. Taki rodzaj znajomości jest kulturowo mitologizowany i przedstawiany jako przynoszący wymierne korzyści oraz bardziej atrakcyjny społecznie aniżeli przyjaźń z kobietą. Trzeba przy tym wszystkim pamiętać o schizofreniczności patriarchalnej kultury, w której z jednej strony takie relacje się waloryzuje i wyróżnia, a z drugiej obciąża bardzo dużym bagażem "trudnych" narracji (za bliska bliskość mężczyzn).

Jak jednak kwestia męsko-męskiej przyjaźni (bliskości) przedstawia się tam, gdzie obaj mężczyźni są homoseksualni? Tworzący na przełomie XIX i XX wieku niemiecki badacz i aktywista Benedict Friedlaender uważał, że homoseksualność jest najwyższym, najdoskonalszym ewolucyjnie etapem w procesie różnicowania genderowego. James Steakley tak pisze o tej tezie: „homoseksualista, jako niepotrzebujący kobiet i kobiecości, postrzegany mógł być jako twórca patriarchalnego społeczeństwa, a w związku ze swoimi predyspozycjami do zachowań heroicznych i przywódczych, powinien być stawiany ponad heteroseksualistą" (1975: 54). Mężczyźni niepotrzebujący kobiet, skupieni na sobie, wolni od przymusu reprodukcyjnego stają się kwintesencją męskości. llustracją dla przedstawionej koncepcji mieliby być na przykład spartańscy wojownicy, wśród których byli podobno również walczący do końca kochankowie. Z poglądami Friedlaendera wydaje się korespondować jedna z wypowiedzi mojego rozmówcy:

Czuję się homoseksualnym mężczyzną. Co jest też dziwnym konstruktem dlatego, że to pierwsze słowo: "homoseksualny" zawiera w sobie już pewne odstępstwo od normy, tej idealnej, prawda? Idealny facet to jest ...uber, czy jak to się tam nazywało, biały, europejski, heteroseksualny mężczyzna. Natomiast wydaje mi się, że jest to jakieś tam zmiękczenie mimo wszystko, nie zmiękczenie na zasadzie zachowania, ale... może nawet przez to zmiękczenie, w jakimś sensie podbicie, dlatego że zawsze mi się wydawało, że jeżeli facet pragnie drugiego faceta to jest 
dwustuprocentowym facetem. Że tak naprawdę ta kwestia męskości jest przez niego podnoszona już do takiej rangi, że właściwie nie pozostaje miejsce na... na pewną potrzebę kobiecości. (Kamil: 28)

Gejostwo jest dla wielu moich respondentów zarówno kwintesencją męskości, jak i oznaką fascynacji nią. Chcą ją "studiować” i praktykować, w niej się obracać; zaś zespolenie dwóch mężczyzn jest przez nich odbierane jako emanacja supermęskości. Z niedowierzaniem przyjmują kulturową opowieść o inherentnym skonfliktowaniu dwóch kategorii: homoseksualności i męskiej tożsamości płciowej. Tomek z kolei zwraca uwagę na homoerotyczny kontekst wszelkich relacji między mężczyznami - nie tylko między tymi, którzy są gejami, co siłą rzeczy przypomina o koncepcji homospołeczności Eve Kosofsky Sedgwick (1985). Tomek jest świadomy atrakcyjności stereotypowej wersji męskości, a ze względu na mniej lub bardziej dosłowną widoczność homoerotyczności kontaktów między (wszelkimi) mężczyznami, możliwe jest, jego zdaniem, także włączenie gejów w symboliczny obszar męskości:

Męskość homoseksualna - to nie jest dla mnie oksymoron, to aż zbyt się nakłada na siebie czasami. Znaczy widzę przede wszystkim to, że - to jest jakby taka moja obserwacja tej kultury - że mnóstwo takich typowo męskich, zagęszczonych zachowań ma jakieś takie podłoże homoseksualne, homoerotyczne, że to jest jakaś taka próba ujednolicenia w stronę męskości, i że to znajduje oddźwięk, czyli zupełnie nie widzę tu sprzeczności. (Tomek: 23)

Również dla Tima Edwardsa (2005: 51) męskość homoseksualistów jest potwierdzana przez pożądanie męskości, zaś zdyskursywizowanie tego faktu i włączenie go do osobistej narracji może pomóc/pomaga zredukować naczelny dysonans towarzyszący wielu homoseksualnym mężczyznom: "ja jako mężczyzna” i „ja jako gej” (wraz z wpisywaną w tę kategorię niemęskością).

Innym podnoszonym w kontekście rehabilitowania/restytuowania gejowskiej męskości zabiegiem narracyjnym jest powoływanie się na mit męskiego braterstwa i czynienie analogii pomiędzy nim a instytucją męsko-męskiej przyjaźni (gdzie każdy z mężczyzn jest homoseksualistą). Bliskie relacje pomiędzy gejami - wolne od trwogi o bycie posądzonym o homoseksualizm - mają dowodzić w pełni dojrzałej męskości tychże. Męskości z czasów, gdy bliskie kontakty między mężczyznami nie 
były obciążone „seksualnym/genderowym szantażem”, a za którymi to mają podobno tęsknić heteroseksualiści. Kamil postrzega bliskie - czasami bardzo intymne - relacje z innymi homoseksualnymi mężczyznami nie tylko jako dowód więzi, czy też wyraz przyjaźni, ale także wyraźnie łączy je z koncepcją męskości. Jego zdaniem, „prawdziwa przyjaźń" jest możliwa tylko między mężczyznami i wyłączone są z niej kobiety. Zdaniem respondenta, geje nie mogą być wyłączeni z definicji męskości także dzięki istnieniu cielesnej dosłowności - dopełniającej kulturowy stereotyp o męskiej przyjaźni i wiążącej się czasami z hasłem o bliskości mężczyzn:

[o "gejostwie" - BL] To jest pewnego rodzaju braterstwo. To jest braterstwo na zasadzie takiej, żeby sobie gdzieś wspólnie pojechać, żeby sobie wzajemnie pomóc, pomóc coś załatwić, pogadać ze sobą gdy jest źle. Nigdy nie starałem się tego zanalizować. Nie wiem, czy to jest normalna relacja miłości, czy właśnie bardziej w facecie szukam czegoś na kształt przyjaciela, z ewentualną opcją chodzenia ze sobą do łóżka. [...] Druga rzecz jaka kojarzy mi się z męskością to umiejętność budowania trwałych przyjaźni. Mam wiele koleżanek, które potrafią być przyjaciółkami dla mnóstwa ludzi. Natomiast męska przyjaźń jest budowana w pocie czoła, przez dość długi okres czasu i zazwyczaj musi się zdarzyć coś naprawdę niefajnego, żeby ją w ogóle zerwać. Ta przyjaźń męska jest oparta na bardziej konkretnych podstawach. To niewiele ma wspólnego, chociaż nie! $\mathrm{Na}$ pewno ma bardzo wiele wspólnego z gejostwem: jest jeszcze taki mit Spartan, którzy idą do boju, ramię w ramię. (Kamil: 28)

Cielesna bliskość, o której wspomina mój rozmówca; bliskość, oznaczająca czasami także współżycie seksualne, jest czymś co wyróżnia niektóre przyjacielskie, "kumpelskie" relacje dwojga homoseksualnych mężczyzn. Zwyczajowo wyłącza się z definicji przyjaźni możliwość utrzymywania przez strony kontaktów seksualnych. Jeśli takie występują, traktowane są raczej jako zwiastun kresu tradycyjnej znajomości i przekształcenia jej w związek (lub inną relację o charakterze erotycznouczuciowym). Jakkolwiek duża część gejów pozostaje pod wpływem takiego rozumienia przyjaźni i tak też interpretuje/definiuje potencjalnie zmieniającą się dynamikę znajomości z drugim człowiekiem (nie zapominajmy, że każdy członek zbiorowości jest pod wpływem tych samych mechanizmów socjalizacyjnych), to jednak dla niektórych "odmieńców” fakt uprawiania seksu z bliskimi bądź dalszymi przyjaciółmi nie jest rzeczą niezwykłą ani niepokojącą. Inny niż dominujący 
w kulturze status seksu i dyskursów seksualności w gejowskich narracjach jest egzemplifikacją tez Foucaulta o laboratoryjnej (w znaczeniu: przyczyniającej się do zmiany, wynalazczej) funkcji seksualności uwolnionej od klisz (Plant 2007). To głównie w dyskursach nienormatywnych rozgrywa się nieekskluzywne patrzenie na sferę seksu, jak również aplikowanie jej do bliskich, intymnych relacji pomiędzy mężczyznami jako czegoś mającego potencjał umacniania lub potwierdzania zażyłości i bliskości. Więzotwórcza rola seksu była już dokumentowana m.in. w pismach Judith Stacey (2004) czy Kate Weston (1991), dotyczących koncepcji "rodzin z wyboru” (pięknie wizualizowanej w fotografiach Nan Goldin). Także Peter Nardi i Drury Sherrod (1994) badali rolę przyjaźni w życiu gejów i lesbijek, zwracając szczególną uwagę na miejsce seksualnej aktywności w jej realizacji. Jakkolwiek wyłącza się z seksualnych kontaktów najbliższych przyjaciół ("best friends”), to jest to już możliwe i praktykowane w odniesieniu do "kumpli" ("casual friends") i bliskich przyjaciół ("close friends”) (Nardi, Sherrod 1994: 191). Nardi - powołując się na własne badania zwraca uwagę, że geje, w swojej często nienormatywnej przyjaźni z innymi homoseksualnymi mężczyznami, dają dowód dobrze odebranej lekcji męskości (1992b: 178). Jednym z jej skryptów jest wysoka seksualna aktywność - przy jednoczesnych niedoborach komunikatów o innych możliwych formach okazywania sobie uczuć, chłopcy w ten właśnie sposób najczęściej rozumieją manifestowanie bliskości. W przypadku mężczyzn heteroseksualnych ekwiwalentem będzie, nierzadko zawodząca i płytka emocjonalnie, relacja z kobietami. Nie inaczej bywa z pewnością w przypadku gejów; jednak części z nich udaje się uznać seks za jeden z ważnych komponentów stanowiących o jakości intymnych, bliskich relacji z drugim człowiekiem (mężczyzną), nie zaś za komponent jedyny. Można zaryzykować tezę, że ten sposób „praktykowania przyjaźni” zakłada pewien poziom urefleksyjnienia podmiotów ${ }^{3}$.

W tym krótkim artykule starałem się przedstawić konsekwencje pojawienia się nowoczesnego dyskursu o (homo)seksualności dla (przede wszystkim) męsko-męskich przyjaźni. Degradacja korporalnej, emocjonalnej bliskości pomiędzy dwojgiem mężczyzn (w obawie o homoseksualny charakter takiego usytuowania w przestrzeni) skutkowała, jak pisze Foucault, końcem romantycznej przyjaźni. Uczuciowa "niepełnosprawność" wielu współczesnych mężczyzn żyjących w zachodniej kulturze - również przekładająca się na "ojcowskie" niekompetencje i nieumiejętności - jest bezpośrednim skutkiem procesów, które rozpoczęły się jeszcze w XVII/XVIII wieku. Z tej pułapki,

\footnotetext{
${ }^{3}$ Nie realizowałem nigdy własnych badań, które mogłyby weryfikować tę hipotezę w odniesieniu do relacji męsko - żeńskich. Nie spotkałem się również z omówieniem tego tematu w literaturze, co jednak nie musi wcale dowodzić nieprawdziwości tego założenia. W przypadku mężczyzn homoseksualnych, niektóre z przedstawionych uwag znajdują moje własne, autoetnograficzne uzasadnienie.
} 
trochę na przekór dominującemu dyskursowi, udaje się uciec niektórym gejom. Subwertując definicje rodziny i intymności oraz przyjaźni, separują się oni od tradycyjnego rozumienia męskości, które wyklucza dwuznaczną bliskość mężczyzn (albo może właściwszym byłoby napisać, że niektórzy homoseksualni mężczyźni powracają do "przed-tradycyjnego" spojrzenia na męskość i bliskość, jeśli oczywiście "tradycyjne” oznacza tutaj wynalezione w czasach nowoczesnych). Ewentualny powrót do praktyki "romantycznej przyjaźni" między mężczyznami stanie się możliwy tylko wtedy, gdy - niezależnie od charakteru ich seksualności - męskie podmioty zaczną okazywać dużo większą refleksyjność oraz gotowość do uplastyczniania prywatnego rozumienia tożsamości płciowej. Nie mniej ważna jest społeczna narracja obecna w dyskursie, która może być albo motywująca albo powstrzymująca

\section{BIBLIOGRAFIA}

Anderson, Eric. 2006. Gay athletes. Contesting hegemonic masculinity in a homophobic environment. W: (red.) Whitehead, Stephen, M. Men and masculinities. Critical concepts in sociology. Tom III. London, New York: Routledge, s. 200-216.

Boswell, John. 2006. Chrześcijaństwo tolerancja społeczna i homoseksualność. Geje i lesbijki w Europie Zachodniej od początku ery chrześcijańskiej do XIV wieku. Kraków: Zakład Wydawniczy NOMOS.

Connell, Raewyn. 2005. Masculinities. Cambridge: Polity Press.

Davis, Whitney. 2004. History and the laboratory of sexuality. UC Berkeley History of Art Department. http://arthistory.berkeley.edu/davis/Foucault.pdf; dostęp: 10.01.2008.

Edwards, Tim. 2005. Queering the pitch? Gay masculinities. W: (red.) Kimmel, Michael S., Hearn, Jeff, Connell, Robert W.. Handbook of studies on men \& masculinities. Thousand Oaks, London, New Delhi: SAGE Publications, s. 51-68.

Epstein, Debbie. 2006. Real boys don't work. "Underachievement", masculinity and the harassment of "sissies". W: (red.) Whithead, Stephen M., Men and masculinities: critical concepts in Sociology. London, New York: Routledge, s. 288-295.

Fee, Dwight. 2000. "One of the guys". Instrumentality and intimacy in gay men's friendships with straight men. W: (red.) Nardi, Peter. Gay masculinities. Thousand Oaks, London, New Delhi: SAGE Publications, s. 44-60.

Foucault, Michel. 2000. Historia seksualności. Warszawa: Czytelnik.

---. 1993. Nadzorować i karać. Narodziny więzienia. Warszawa: Aletheia.

Garlick, Steve. 2002. The beauty of friendship. Foucault, masculinity and the work of art. W: "Philosophy \& Social Criticism" 28, s. 558-577.

Nardi, Peter. 1992a. "Seamless souls". An introduction to men's friendships. W: (red.) Nardi, Peter. Men's friendships. Newburry Park, London, New Delhi: SAGE Publications, s. 1-6. 
---. 1992b. Sex, friendship, and gender roles among gay men. W: (red.) Nardi, Peter. Men's friendships Newburry Park, London, New Delhi: SAGE Publications, s. 175-184.

Nardi, Peter, Drury Shrerod. 1994. Friendship in the lives of gay men and lesbians. W: "Journal of Social and Personal Relationships"11, s. 185-199.

Oransky, Matthew, Jeanne Marecek. 2009. "I'm not going to be a girl". Masculinity and emotions in boys' friendships and peer groups. W: "Journal of Adolescent Research" 24, s. 218-241.

Plant, Bob. 2007. Playing games/playing us. Foucault on sadomasochism. W: "Philosophy \& Social Criticism" 33, s. 531-561.

Plummer, David. 2006. Sportophobia: why do some men avoid sport? W: "Journal of Sport and Social Issues" 30, s. 122-137.

Pronger, Brian. 1999. Outta my endzone: sport and the territorial anus. W: "Journal of Sport and Social Issues" 23, s. 373-389.

Sedgwick Kosofsky, Eve. 1985. Between men. English literature and male homosocial desire. New York: Columbia University Press.

Seidler Jeleniewski, Victor. 2007. Masculinities, bodies, and emotional life. W: "Men and Masculinities" 10, s. 9-21.

Stacey, Judith. 2004. Cruising to familyland: gay hypergamy and rainbow kinship. W: "Current Sociology" 52, s. 181-197.

Steakley, James. 1975. The homosexual emancipation movement in Germany. New York: Arno Press.

Stoudt, Brett. 2006. "You're either in, or you're out". School violence, peer discipline, and the (re)production of hegemonic masculinity. W: "Men and Masculinities" 8, s. 273-287.

Weston, Kate. 1991. Families we choose: lesbians, gays, kinship. New York: Columbia University Press.

Whitson, David. 1990. Sport in the social construction of masculinity. W: (red.) Messner, Michael, Sabo, Donald F. Sport, men, and the gender order. Critical feminist perspectives. Champaign: Human Kinetics Books, s. 19-29. 